\title{
Evaluation of Broccoli Residue Incorporation into Field Soil for Verticillium Wilt Control in Cauliflower
}

\author{
Krishna V. Subbarao and Judith C. Hubbard, Department of Plant Pathology, University of California, Davis, \\ United States Agricultural Research Station, Salinas 93905; and Steven T. Koike, University of California Coop- \\ erative Extension, Salinas 93901
}

\begin{abstract}
Subbarao, K. V., Hubbard, J. C., and Koike, S. T. 1999. Evaluation of broccoli residue incorporation into field soil for Verticillium wilt control in cauliflower. Plant Dis. 83:124-129.

Wilt incited by Verticillium dahliae has recently become an important disease on cauliflower in the Salinas Valley. Although broccoli is closely related to cauliflower, wilt has not occurred on this host and $V$. dahliae isolates from cauliflower were weakly pathogenic on broccoli in greenhouse inoculations. In this study, the effectiveness of broccoli residues on propagule attrition in soil and wilt incidence on cauliflower was determined in a commercial field infested with $V$. dahliae microsclerotia. The treatments were broccoli residue with tarp, broccoli residue without tarp, chloropicrin, metham sodium, control with tarp, control without tarp, cauliflower followed by cauliflower, and cauliflower followed by fallow. Approximately $200 \mathrm{~kg}$ of chopped broccoli was uniformly disk incorporated into the corresponding plots $\left(36 \mathrm{~m}^{2}\right)$. Densities of $V$. dahliae microsclerotia were determined at 0,30, 90, and 145 days after treatment in 1993 and 0, 30, 74, 109, and 140 days after treatment in 1994 using the modified Anderson sampler technique. Cauliflower cultivar White Rock was planted in all plots. Plant height, number of marketable heads, head weight, and wilt severity were determined at maturity. Even though the pre-treatment number of $V$. dahliae propagules in broccoli-treated and control plots were similar, by the end of the cauliflower cropping season numbers either were the same or increased in control plots compared with a reduction in numbers in broccoli residue-treated plots during both seasons. There were no differences between tarped and non-tarped plots either in broccoli residue-treated or control plots. In fumigated plots, propagules declined initially but later returned to pre-treatment levels by the end of the cropping season. Continuous cauliflower or fallowing after one cauliflower crop resulted in stable or increased levels of microsclerotia. Verticillium wilt severity was lowest in metham sodium-treated plots, followed by broccoli residue-treated plots and chloropicrin in both years. Plant height, marketable heads, and head weight were higher in broccoli-treated than in control plots. These results suggest that broccoli residues reduce $V$. dahliae microsclerotia in soil and wilt of cauliflower as much as or more than chloropicrin and metham sodium, and that rotation with broccoli may be a feasible approach to manage Verticillium wilt in cauliflower and other susceptible crops.
\end{abstract}

Additional keywords: Crop rotation, cultural control, soilborne pathogens

Cauliflower (Brassica oleracea L. var. botrytis L.) is an important vegetable crop in coastal California, where more than $75 \%$ of the cauliflower in the United States is produced. In recent years, wilt caused by Verticillium dahliae Kleb. has severely affected commercial cauliflower production. Disease symptoms on cauliflower, including chlorosis of lower leaves, defoliation, wilting, and vascular discoloration, result in reduced size and quality of the harvested heads (10).

Because of the prolonged survival of microsclerotia, up to 13 years in infested

Corresponding author: K. V. Subbarao

E-mail: kvsubbarao@ucdavis.edu

This work was supported in part by the various cauliflower growers of coastal California.

Accepted for publication 13 October 1998.

Publication no. D-1998-1130-03R

(C) 1999 The American Phytopathological Society soils (16), a key to managing Verticillium wilt is to reduce the number of microsclerotia in soil to levels too low to cause disease on susceptible crops. Reductions in soilborne microsclerotia are usually accomplished with a combination of chemical (21) and cultural methods $(4,6)$. Host resistance is unavailable in most crops, including cauliflower. The imminent loss of methyl bromide will leave fewer alternative fumigants for effective management of Verticillium wilt.

Interest in non-chemical approaches to managing soilborne diseases has been rekindled with the recent emphasis on sustainable agriculture. Brassicaceae crop residues $(1,3,9,12-15)$ reduce propagules of soilborne pathogens and result in a concomitant decrease in the incidence of plant diseases $(4,20,22)$. The effects of crucifer residues have been attributed to the chemical breakdown of glucosinolates, the characteristic sulfur-containing constituents of the members of Brassicaceae responsible for their inherent pungent odor $(1,7)$. Dur- ing the decomposition of crucifer residues, glucosinolates break down to produce sulfides, isothiocyanates, thiocyanates, and nitriles, compounds that have either fungistatic or fungicidal properties $(1,7)$. The types and amounts of glucosinolates vary with the crucifer species $(1,11)$ and determine the level of plant pathogen growth reduction. Soil amendments with crucifer residue combined with solarization produce a greater variety of toxic volatile substances and improves the effectiveness of solarization $(5,14,15)$. The activity of crucifer residues on soilborne diseases are reported to be greater when the crucifer residue is dry at the time of soil incorporation (15) and are positively correlated with the amount of glucosinolate in the crop (11).

Even though broccoli (B. oleracea L. var. botrytis L.) and cauliflower are closely related, Verticillium wilt has not occurred in commercial broccoli crops planted in heavily infested soils (10). Neither does the broccoli plant support the formation of microsclerotia on its roots. Attempts to isolate the pathogen from broccoli plants collected from infested fields were unsuccessful. Isolates of $V$. dahliae from cauliflower were weakly pathogenic to broccoli in greenhouse tests (18), and attempts to re-isolate the pathogen from inoculated plants at maturity were unsuccessful.

Recent studies have determined that fresh broccoli residue suppresses $V$. dahliae microsclerotia more than dry broccoli residue over the entire temperature range tested $\left(10\right.$ to $\left.35^{\circ} \mathrm{C} ; 19\right)$. Furthermore, the greatest reductions in microsclerotia occur at soil temperatures above $20^{\circ} \mathrm{C}$ with both fresh and dry broccoli residue, and most of this reduction occurs within 15 days of incorporation (19). Thus, for maximal reductions in soilborne $V$. dahliae microsclerotia, the broccoli residues should be incorporated when the soil temperatures are at least $20^{\circ} \mathrm{C}$.

The objectives of this study were to (i) investigate whether incorporation of broccoli residue effectively reduces $V$. dahliae microsclerotia and the incidence of Verticillium wilt on cauliflower in a commercial field, (ii) determine if tarping after incorporation increases the effectiveness of broccoli residue, and (iii) compare broccoli residue with metham sodium and chloropicrin normally used to reduce soilborne pathogens. Preliminary results have been published (20). 


\section{MATERIALS AND METHODS}

Experimental site. Experiments were conducted during June to September of 1993 and 1994 in a grower's field with a history of severe Verticillium wilt of cauliflower. The soil was a Chualar sandy loam, $\mathrm{pH} 6.9$, consisting of $47.8 \%$ sand, $43.0 \%$ silt, $6.8 \%$ clay, and $2.4 \%$ organic matter. The field had been under vegetable production for at least 10 years, and was under a cauliflower-lettuce rotation with an occasional celery crop.

Soil samples were collected randomly to a depth of $25 \mathrm{~cm}$ from the experimental site and assayed for $V$. dahliae microsclerotia using the modified Anderson sampler technique (2). During the study, no other crop was grown in the experimental area nor were any unrelated tillage operations undertaken.

Treatments and experimental design. The experiment included eight treatments: 1, broccoli residue with tarp; 2 , broccoli residue without tarp; 3 , control with tarp; 4 , control without tarp; 5 , cauliflower followed by cauliflower; 6 , cauliflower followed by fallow; 7 , metham sodium (563 liters/ha); and 8, chloropicrin (543 kg/ha). Treatments 4 and 5 in this study were identical during both years. The treatments were arranged in a randomized complete block design with four replications. Individual plots were $9 \mathrm{~m}$ long and 4 beds wide ( $1 \mathrm{~m}$ between bed centers) with $2 \mathrm{~m}$ of bare soil between replications to reduce plot interactions (total area per plot $=36 \mathrm{~m}^{2}$ ). In addition, metham sodium- and chloropicrin-treated plots were also separated from other plots by $2 \mathrm{~m}$ of bare soil to reduce cross contamination. The experimental site was pre-irrigated with sprinklers 4 days before treatment to ensure adequate soil moisture during application of chemicals and other treatments.

The amount of broccoli residue incorporated into experimental plots was determined by harvesting and weighing the remaining broccoli biomass from several commercial production fields after broccoli heads were harvested. An average of 205 $\mathrm{kg}$ of broccoli residue remained in a $36-\mathrm{m}^{2}$ area. Freshly harvested, chopped broccoli residue was obtained from a food processor (Norcal Crosetti Foods, Inc., Watsonville, $\mathrm{CA}$ ) and uniformly spread across each plot at a rate of $205 \mathrm{~kg} / \mathrm{plot}$, then disk incorporated to a depth of 25 to $30 \mathrm{~cm}$. Clear, 3mil-thick plastic was spread across the treatments involving tarping and the edges were sealed with soil. After 2 weeks, tarps were removed and beds shaped.

Chemical treatments were applied 1 week after the above treatments were initiated. Metham sodium (563 liters/ha) and chloropicrin $(543 \mathrm{~kg} / \mathrm{ha})$ were applied into the planting beds using three shanks with multiple ports by a commercial applicator (Tri-Cal, Hollister, CA) and the beds treated with these chemicals were not tarped.
A total of 4 weeks after broccoli residue incorporation, Verticillium wilt-susceptible cauliflower cultivar White Rock was direct-seeded into all plots in single rows. At 2 weeks after emergence, seedlings were thinned to a $25-\mathrm{cm}$ spacing between plants. Throughout the cropping season, sprinklers irrigated the plots and irrigation and fertilization schedules recommended for cauliflower in this area were followed. During 1994, cauliflower was not planted in the cauliflower + fallow treatment.

Cauliflower plants in each plot were monitored for Verticillium wilt development. The time of disease onset in each treatment was determined by randomly sampling two plants each week from each plot to evaluate vascular discoloration. Pieces of root and stem tissue from each treatment were surface-sterilized with $0.5 \% \mathrm{NaOCl}$ and plated on NP-10 selective medium (17) and incubated in the dark at room temperature $\left(2224^{\circ} \mathrm{C}\right)$. The medium and tissue pieces were examined periodically for the presence of $V$. dahliae microsclerotia and conidiophores.

To determine the level of stress in cauliflower plants under the different treatments, two visually healthy (upper) and two disease-induced chlorotic (lower) leaves in each treatment were marked, and the stomatal resistance in these leaves was measured systematically using a porometer (Delta-T Devices, Cambridge, England). Measurements were taken on sunny days at 1300 to $1500 \mathrm{~h}$ four times at 3-week intervals after wilt symptoms appeared in most treatments. For individual leaves, five readings of the porometer were taken and averaged. Porometer readings were converted to leaf stomatal resistance (seconds per centimeter) using a calibration curve from the corresponding day.

Yield, plant height, and disease determinations. Yield data were collected from the middle two rows of each plot. Because flowering in cauliflower is variable, commercial fields are harvested at least twice. In this experiment, commercial practices were followed and harvesting was begun when at least $60 \%$ of the plants had produced marketable heads. Second harvest was made 1 week later. For each treatment, the total number of marketable heads was counted and their weight determined. At the time of the first harvest in 1993, heads in the chloropicrin and metham sodium treatments were too mature to obtain reliable data, and hence the data were excluded from the analyses.

Plant height in each treatment was measured just prior to harvest on 10 randomly chosen plants in the middle two rows of each plot. Immediately after harvest, 10 plants in the middle two rows of each plot in each treatment were randomly uprooted and washed free of soil; then the stem and root of each plant was longitudinally split to estimate the percentage of vascular tissue discolored (severity) on a scale of 0 to 5 , where $0=$ no discoloration, $1=1$ to $10 \%$ discoloration, $2=11$ to $30 \%$ discoloration, $3=31$ to $50 \%$ discoloration, $4=51$ to $75 \%$ discoloration, and $5=76$ to $100 \%$ discoloration. To confirm that the discoloration was a result of Verticillium wilt, pieces of diseased root and stem tissue from each of these plants were surfacesterilized, plated on NP-10 medium, and incubated at room temperature (22 to $24^{\circ} \mathrm{C}$ ). The plates were examined periodically for the development of $V$. dahliae colonies.

Pre- and post-treatment soil sampling and processing. The initial densities of $V$. dahliae microsclerotia in all experimental plots were determined by sampling the soil with a $2.5-\mathrm{cm}$-diameter core to a depth of $25 \mathrm{~cm}$. In each plot, soil was sampled at 10 randomly chosen sites and bulked. Subsequent soil samples were collected at 30, 90, and 145 days after the treatments were applied in 1994, and at 30, 74, 109, and 140 days in 1995. Samples were air-dried for 6 weeks and assayed for microsclerotia by plating the soil on NP-10 medium using the modified Anderson sampler technique and incubating in the dark at room temperature. After 3 weeks of incubation, the number of $V$. dahliae colonies per plate were counted under a $10 \times$ stereoscope.

Data analysis. Differences between treatments for cauliflower yield, plant height, and wilt severity were determined by analysis of variance, and means were compared by the least significant difference test $(P \leq 0.05)$. The analysis of variance indicated that there was no year $x$ treatment interaction for plant height and yield; therefore, the results from a combined analysis are presented. Numbers of microsclerotia in each treatment were expressed as microsclerotia $\mathrm{g}^{-1}$ of dry soil. Means and the corresponding standard errors were computed for each treatment and sampling time. Repeated measures analysis of variance was used to test stomatal resistance in leaves from different treatments recorded over time. All analyses were done using SAS (release 6.12 ed., SAS Institute, Cary, NC).

\section{RESULTS}

Detection of $\boldsymbol{V}$. dahliae infection. Infection of cauliflower was detected 5 weeks after transplanting in all treatments except metham sodium and chloropicrin. First infection of plants in metham sodium and chloropicrin treatments was detected during the following week, when consistent differences in the proportion of infected plants in the different treatments were discernible. In broccoli residue, metham sodium, and chloropicrin treatments, the pathogen was recovered from 3 of 8 plants sampled, in contrast to the 4 to 5 sampled plants in control plus tarp, control minus tarp, cauliflower followed by cauliflower, and cauliflower followed by fallow (only in 1993) treatments. Similar 
differences persisted during subsequent sampling times and, at crop maturity, the pathogen was recovered from 5 out of 8 sampled plants in metham sodium and the two broccoli treatments. In the chloropicrin treatment, 6 out of 8 sampled plants yielded $V$. dahliae colonies. In the remaining treatments, however, 7 or 8 out of 8 sampled plants were infected at maturity.
Population dynamics of $V$. dahliae microsclerotia. Pre-treatment densities of $V$. dahliae microsclerotia were similar in all treatments in both years except in metham sodium plots in 1993. At 30 days after broccoli residue incorporation, the numbers of microsclerotia were reduced compared to pre-treatment levels (Fig. 1). The numbers continued to decline throughout the cauliflower season in both broccoli residue treatments, though most reduction occurred in the first 30 days (Fig. 1). Regardless of the sample time, there were no differences in the populations of microsclerotia between tarped and non-tarped broccoli treatments. The reduction in the number of microsclerotia was nearly $50 \%$ in both broccoli treatments in 1993 and was nearly $75 \%$ in 1994 (Fig. 1). In contrast to the broccoli residue-treated plots, metham
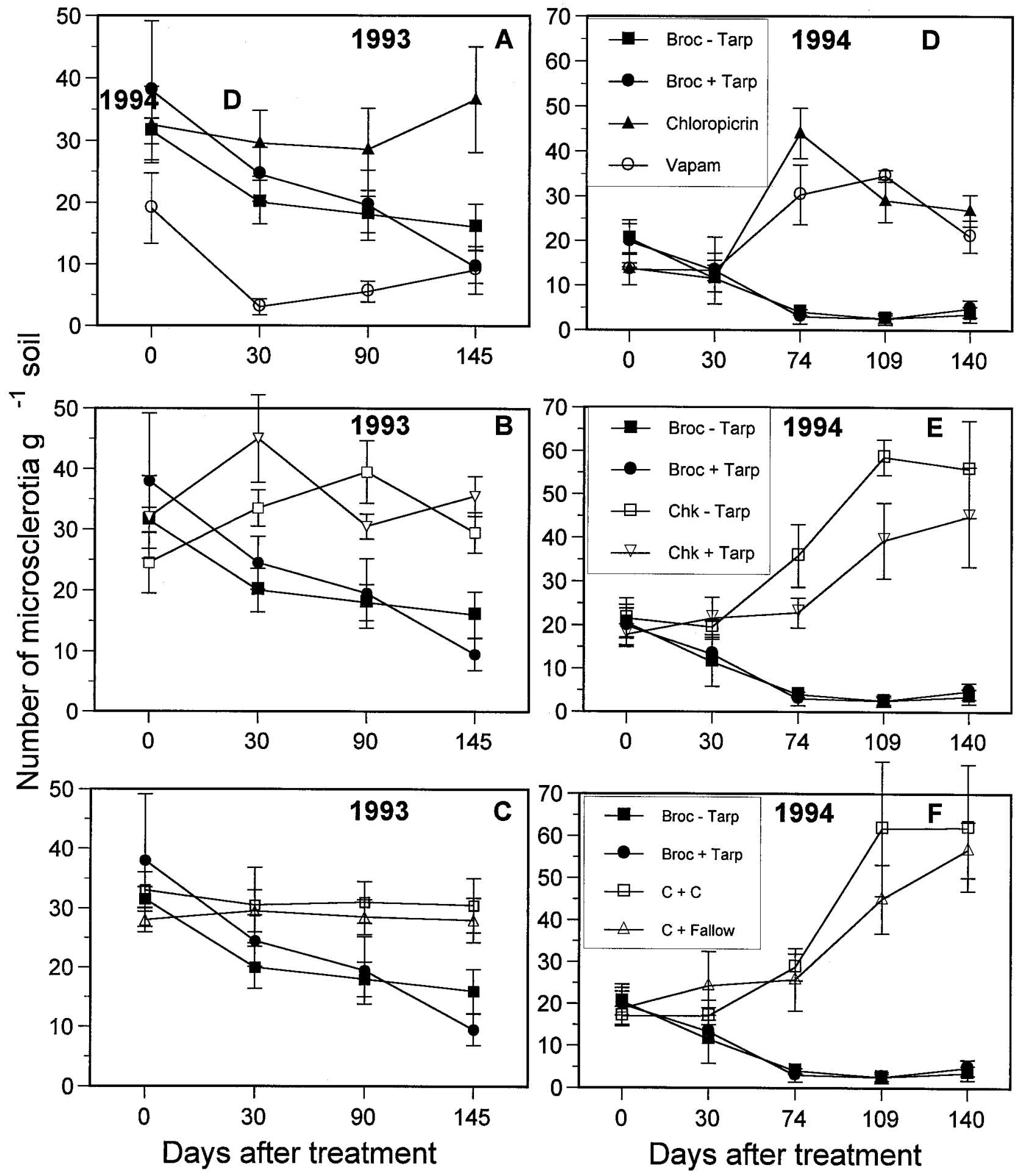

Fig. 1. Population dynamics of Verticillium dahliae microsclerotia in the different treatments prior to (early June) or at various times after the treatments were introduced (June to September). The data are the mean of four replications each year. The vertical bars are the standard errors of the mean. The corresponding legends for (A, B, and $\mathbf{C})$ are the same as for (D, E, and F), respectively. 
sodium and chloropicrin treatments resulted in immediate declines in the numbers of microsclerotia, but after 30 days the numbers progressively increased again in both years. However, this increase was significant only in 1994 (Fig. 1A and D). Microsclerotia in tarped or non-tarped control plots fluctuated during the 1993 cropping season, but the final populations were nearly the same as the initial populations (Fig. 1B and E). In 1994, however, populations of microsclerotia in both tarped and non-tarped control treatments increased throughout the season and the final populations were more than twice that of the initial populations (Fig. 1). The dynamics of microsclerotia in cauliflower followed by cauliflower and cauliflower followed by fallow were nearly identical to the tarped or non-tarped control treatments in both years. Final populations either remained the same (in 1993) or increased nearly 200\% (in 1994) (Fig. 1C and F).

Wilt severity, stomatal resistance, and cauliflower growth and yield. During both years, the average Verticillium wilt severity was lowest in the metham sodium treatment and was significantly different from all other treatments except for broccoli residue without tarping in 1994 (Fig. 2). Wilt severity in chloropicrin and broccoli, with or without tarping, was identical during both years. In the other treatments, the wilt severity was higher than in treatments discussed above during both years (Fig. 2).

Repeated measures analysis of variance indicated that in the upper, apparently healthy cauliflower leaves, stomatal resistance was not significantly different between treatments regardless of the time of measurement during the crop season $(P>$ 0.2065 to 0.8040 ). Regardless of the treatments, stomatal resistance was highest just before crop maturity. In the diseased, lower leaves, however, stomatal resistance was significantly different between the treatments in two of the three sample times $(P$ $=0.0034$ and 0.0004 for times 2 and 3 , respectively). Thus, effect of time was also highly significant ( $P$ for Wilks' $\lambda=$ $0.0001)$, and time effects were linear $(P=$ $0.0008)$. The time $\times$ treatment effects were also highly significant ( $P$ for Wilks' $\lambda=$ $0.0003)$, suggesting that the stomatal resistance in the different treatments was not consistent over time. Like the disease severity, stomatal resistance was lowest in the lower leaves of cauliflower plants in broccoli without tarp $\left(14.82 \mathrm{~s} \mathrm{~cm}^{-1}\right)$ and metham sodium $\left(17.86 \mathrm{~s} \mathrm{~cm}^{-1}\right)$ treatments, intermediate in broccoli with tarp $(22.0 \mathrm{~s}$ $\mathrm{cm}^{-1}$ ), and high in the remaining treatments (>34.51 s cm ${ }^{-1}$ ).

Plant height was also significantly different between the treatments. Plants in the metham sodium, chloropicrin, and broccoli with or without tarping treatments were significantly taller than in other treatments (Table 1). Similarly, harvested head weight
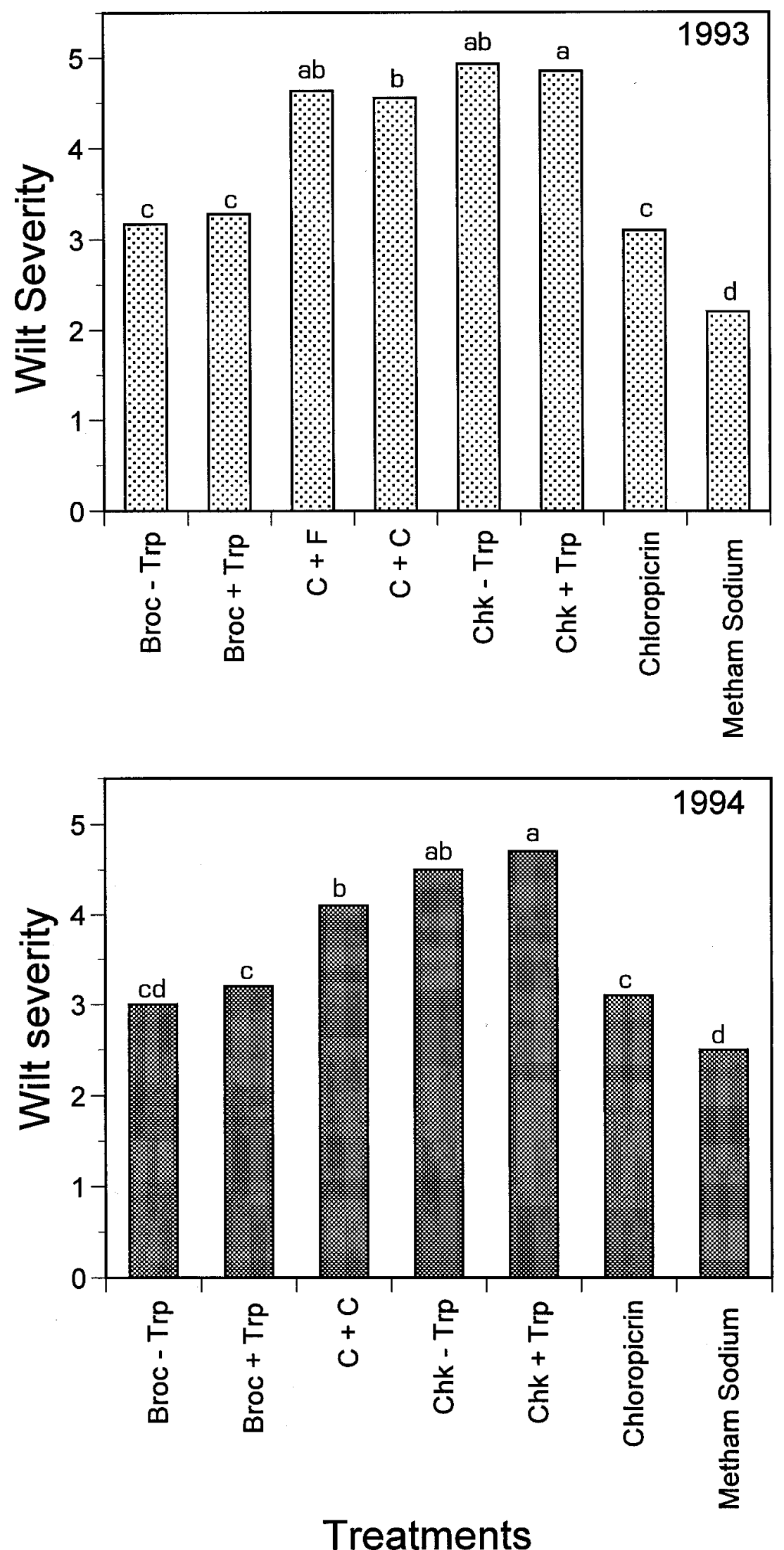

Fig. 2. Verticillium wilt severity in the different treatments in 1993 and 1994. The severity was scored on a scale of 0 to 5 , where $0=$ no vascular discoloration in the root and stem, $1=1$ to $10 \%$ discoloration, $2=11$ to $30 \%$ discoloration, $3=31$ to $50 \%$ discoloration, $4=51$ to $75 \%$ discoloration, and $5=76$ to $100 \%$ discoloration. Each bar is the mean of four replications and same letter above the bars indicates lack of statistical difference according to the least significant difference test $(P<0.05)$. One treatment was left fallow; therefore, severity ratings for cauliflower followed by fallow $(C+F)$ are missing in 1994. 
was significantly higher in the metham sodium and broccoli with or without tarping than in all other treatments (Table 1). However, the number of harvested heads in 1993 was the highest in the two broccoli treatments, followed by continuous cauliflower, control plus tarp, and control without tarp (Table 1; results from metham sodium and chloropicrin were not included in the analyses). In 1994, the number of harvested heads was highest in the metham sodium treatment but was similar to the two broccoli treatments. The number of harvested heads was significantly higher than in the other treatments (Table 1). Treatment differences were also discernible in the weight of individual harvested heads. Individual cauliflower heads from metham sodium and chloropicrin plots had the highest weight, followed by the two broccoli residue treatments and others (Table 1).

\section{DISCUSSION}

Results from this study clearly demonstrate that broccoli residue reduces the numbers of $V$. dahliae microsclerotia in soil and the incidence of Verticillium wilt in cauliflower. Although the greatest reduction in the number of microsclerotia was observed within 4 weeks after the incorporation of broccoli residue, the microsclerotia continued to decline throughout the cauliflower cropping season and remained low during the following season in the broccoli residue treatments. In contrast, the numbers stayed the same or increased in the other treatments. This implies that rotation of cauliflower with broccoli could be used to manage Verticillium wilt. Demonstration of crop rotation effects is of long-term nature; therefore, in this study, we saved one season's time by applying broccoli residue at a rate typical of what would remain following a commercial harvest. Nonetheless, the results were similar to those from a subsequent study that utilized cauliflower and broccoli rotations (22). We have also previously determined that reductions in $V$. dahliae microsclerotia do not occur during a broccoli crop but only after the incorporation of the residue (22).

The overall decline in the number of microsclerotia in broccoli residue treatments was generally greater than in plots treated with conventional soil chemical treatments. In contrast to the temporary reductions in the microsclerotia observed with soil chemicals, the populations of microsclerotia in broccoli residue-amended soils remained low throughout the cauliflower season. Each year, the broccoli treatments exhibited a persistent reduction in soil inoculum densities; fumigation treatments were less consistent. Broccoli residue can provide a reduction in $V$. dahliae microsclerotia not only by reducing the resident soilborne microsclerotia but also by preventing their formation on cauliflower roots (22).

The field had previously been cropped for at least 10 years with two crops of lettuce followed mostly by cauliflower and occasionally by celery. The precise timing of infestation by $V$. dahliae microsclerotia affecting cauliflower in this field is unavailable but is unlikely to be earlier than 1990, when the disease was first noticed on cauliflower in the Salinas Valley. Thus, augmentation of soilborne $V$. dahliae microsclerotia may have occurred following an infected cauliflower crop in subsequent years. The dispersal of this inoculum generally occurs upon decay and dispersal of crop debris over several years. Not many cauliflower crops had been grown in this newly infested field; therefore, the volume of infested debris releasing inoculum into the soil may not have been high. Furthermore, it is quite possible that all inoculum present in this field may not have been in a dispersed form when this study was begun. Although the soil chemical treatments showed an immediate reduction in the number of microsclerotia, the numbers either increased or returned to preplanting levels toward the end of the season. Soil chemical treatments are known to be less effective against inoculum in larger chunks or organic debris than free propagules. Thus, a significant portion of the new inoculum produced in the 1993 cauliflower may have persisted and quite likely was responsible for the inoculum increase in late 1994. However, inoculum levels in these treatments were well below those of the checks. In contrast, the inoculum levels in the broccoli treatments remained low during both seasons following the initial decline after the residue incorporation, suggesting that broccoli treatments are effective against both the free inoculum in the soil as well as that on larger chunks or organic debris.

In this study, the decline in $V$. dahliae microsclerotia in both tarped and nontarped broccoli residue treatments was identical; thus, tarping is not necessary for effectiveness. This indicates that volatile compounds released from glucosinolates $(1,5,11)$ during the decomposition of broccoli are not entirely responsible for its action. Such volatile compounds have been implicated as toxicity factors toward a range of plant pathogens, including nematodes $(3,5,7-9,12-15)$. With tarping, solarization effects associated with high temperature (5) were not a factor in this study because tarped controls did not differ from the untarped control.

Glucosinolate breakdown products are volatile; therefore, the likelihood of their extended presence in the vicinity of $V$. dahliae microsclerotia is expected to be shorter. Exposure to these volatiles for a very short period is unlikely to affect the viability of microsclerotia to a great extent. Our results therefore point to mechanisms other than simple chemical fumigation effects of broccoli residue on $V$. dahliae microsclerotia. This phenomenon of pathogen control via broccoli residue is particularly useful because pathogen populations are significantly decreased without the use of expensive plastic tarps and the treatment is effective in California's cool central coast area (approximately 18 to $25^{\circ} \mathrm{C}$ daytime maxima during the summer) where solarization is not particu-

Table 1. Cauliflower plant height and yield components in different treatments in 1993 and 1994 seasons

\begin{tabular}{|c|c|c|c|c|c|c|c|c|}
\hline \multirow[b]{2}{*}{ Treatments } & \multicolumn{2}{|c|}{ Plant height ${ }^{\mathrm{v}, \mathrm{w}}$} & \multicolumn{2}{|c|}{ No. harvestable heads ${ }^{v}$} & \multicolumn{2}{|c|}{ Weight total harvest ${ }^{\mathbf{v}}$} & \multicolumn{2}{|c|}{ Weight per head (g) } \\
\hline & 1993 & 1994 & 1993 & 1994 & 1993 & 1994 & 1993 & 1994 \\
\hline Control + tarp & $49.2 \mathrm{~b}$ & $49.6 \mathrm{~b}$ & $12.3 \mathrm{bc}$ & $11.8 \mathrm{c}$ & $9.6 \mathrm{~b}$ & $9.0 \mathrm{c}$ & 780 & 760 \\
\hline Control - tarp & $48.7 \mathrm{~b}$ & $49.2 \mathrm{~b}$ & $11.3 \mathrm{c}$ & $10.6 \mathrm{c}$ & $9.7 \mathrm{~b}$ & $8.9 \mathrm{c}$ & 860 & 840 \\
\hline $\mathrm{C}+\mathrm{C}^{\mathrm{x}}$ & $49.8 \mathrm{~b}$ & $49.8 \mathrm{~b}$ & $12.0 \mathrm{bc}$ & $12.5 \mathrm{c}$ & $10.1 \mathrm{~b}$ & $10.8 \mathrm{c}$ & 840 & 864 \\
\hline $\mathrm{C}+$ fallow & $49.7 \mathrm{~b}$ & $\ldots{ }^{\mathrm{y}}$ & $12.3 \mathrm{bc}$ & & $10.6 \mathrm{~b}$ & & 860 & \\
\hline Broccoli - tarp & $51.3 \mathrm{ab}$ & $52.3 \mathrm{a}$ & $16.5 \mathrm{ab}$ & $17.0 \mathrm{ab}$ & $15.4 \mathrm{a}$ & $16.1 \mathrm{~b}$ & 930 & 947 \\
\hline Broccoli + tarp & $52.8 \mathrm{a}$ & $53.1 \mathrm{a}$ & $17.3 \mathrm{a}$ & $16.6 \mathrm{ab}$ & $16.5 \mathrm{a}$ & $16.2 \mathrm{~b}$ & 950 & 976 \\
\hline Chloropicrin & $52.7 \mathrm{a}$ & $52.9 \mathrm{a}$ & $\ldots^{\mathrm{z}}$ & $15.4 \mathrm{~b}$ & $\ldots$ & $16.1 \mathrm{~b}$ & 1,000 & 1,045 \\
\hline Metham sodium & $54.0 \mathrm{a}$ & $53.6 \mathrm{a}$ & $\ldots$ & $18.5 \mathrm{a}$ & $\ldots$ & $21.3 \mathrm{a}$ & 1,300 & 1,151 \\
\hline
\end{tabular}

${ }^{\mathrm{v}}$ Mean of four replications. Values followed by the same letters within a column are not significantly different according to the least significant difference test $(P<0.05)$.

${ }^{\text {w }}$ Plant height is the mean of 10 plants in each of the four replications.

${ }^{x} \mathrm{C}+\mathrm{C}=$ cauliflower followed by cauliflower.

${ }^{\mathrm{y}}$ There were no cauliflower plants in this treatment because it was left fallow in 1994.

${ }^{\mathrm{z}}$ Yield data from chloropicrin and metham sodium treatments in 1993 were excluded from the analyses because the plots were over-mature when harvesting was begun in all other treatments. 
larly effective. Our findings can be readily implemented by commercial agriculture. In California, there is a significant broccoli products industry (frozen broccoli, fresh bagged broccoli) that daily generates many tons of discarded broccoli stems, leaves, and florets. Broccoli residues normally fed to livestock could be diverted for use in a soilborne pathogen management program. This practice could also have other potential benefits. Growers in California have observed for many years that where broccoli residues from processing plants are dumped back onto a field, weed populations are reduced the following year. Thus, rotations with broccoli may have multiple pest management benefits.

Lack of significant differences between continuous cauliflower and cauliflower followed by fallow in all the variables studied was not unexpected. Both treatments resulted in significant increases of similar magnitude in soil populations of microsclerotia over the pre-treatment levels. Although fallowing fields in the Salinas Valley even for limited periods is not feasible because of the very high cost of agricultural land, we included this treatment to study the dynamics of microsclerotia under this management system. Microsclerotia formed on woody, infected cauliflower roots evidently are released into the soil over prolonged periods of time by various tillage practices, which were consistent in both treatments. This study covered only 2 years, but these results suggest that a longer-term fallow may result in lower populations of microsclerotia than continuous cauliflower.

Soil temperatures of $>20^{\circ} \mathrm{C}$ are optimal for the broccoli residue-mediated reductions in $V$. dahliae microsclerotia (19). In this study, broccoli residue was incorporated into the soil in June during both years, when the soil temperatures are usually at or above $20^{\circ} \mathrm{C}$. Reduced seed germination, emergence, and stand often is observed immediately following crucifer crops (1). However, we did not observe any differences in the germination rates of cauliflower in broccoli versus non-broccoli treatments in 1993 or 1994 . The intensity of vegetable production in the Salinas and adjoining valleys requires short intervals between crops; however, a decline in the germination of subsequent crops has not been observed.

Plant height and number of harvestable heads were nearly identical in both treatments involving broccoli and the two soil chemicals, except for number of harvested heads in 1993, and these variables were significantly higher in these than in all other treatments. In 1993, however, by the time harvest operations were begun, many plants in plots treated with metham sodium and chloropicrin had over-mature heads that were not harvested and could not be included in the total number of heads or the total weight of all heads. During both seasons, the weight of individual cauliflower heads was highest in plots treated with metham sodium. In 1994, yield data were obtained based on the rate of plant maturity in different treatments, and the total weight harvested was significantly higher than in 1993 in the metham sodium treatment. Thus, broccoli residue not only reduced the soil populations of $V$. dahliae microsclerotia and incidence of Verticillium wilt on cauliflower, but also provided total yields comparable to the soil chemical treatments.

In summary, cauliflower and broccoli are closely related taxonomic species (being different varieties of identical species), yet they differ considerably in their response to $V$. dahliae. In greenhouse tests, broccoli is immune to all $V$. dahliae isolates except those from cauliflower and cabbage, which are only weakly pathogenic to broccoli (18; R. G. Bhat and K. V. Subbarao, unpublished). An effective approach to exploiting the benefits of broccoli-mediated disease suppression is as simple as adapting a rotation of susceptible crops with broccoli. Growers could plow under broccoli residue after commercial harvest of the crop for propagule reduction and Verticillium wilt management in subsequent cauliflower crops. Development of a rotational scheme using broccoli could also reduce the use of synthetic pesticides. In the Salinas and adjoining valleys, rotation with broccoli is compatible with the current production practices (since broccoli is already a major crop there), and would have no adverse environmental effects. This practice might also effectively control Verticillium wilt in other susceptible crops.

\section{ACKNOWLEDGMENTS}

We thank A. Caminey for providing the experimental site; M. Rooney and L. Stevens for providing freshly chopped broccoli residue; TriCal for providing soil fumigants; A. Chassot, K. Fowler, T. Gonzales, A. Lewis, P. Niday, M. Vidauri, E. Oakes, and C. Xiao for assistance; and S. Fennimore for his comments and suggestions on the manuscript.

\section{LITERATURE CITED}

1. Brown, P. D., and Morra, M. J. 1997. Control of soil-borne plant pests using glucosinolatecontaining plants. Pages 167-231 in: Advances in Agronomy, Vol. 61. D. L. Sparks, ed. Academic Press, New York.

2. Butterfield, E. J., and DeVay, J. E. 1977. Reassessment of soil assays for Verticillium dahliae. Phytopathology 67:1073-1078.

3. Chan, M. K. Y., and Close, R. C. 1987. Aphanomyces root rot of peas 3 . Control by the use of cruciferous amendments. N. Z. J. Agric. Res. 30:225-233.

4. Davis, J. R., Huisman, O. C., Westerman, D. T., Hafez, S. L., Everson, D. O., Sorensen, L. H., and Schneider, A. T. 1996. Effects of green manures on Verticillium wilt of potato. Phytopathology 86:444-453.

5. Gamliel, A., and Stapleton, J. J. 1993. Characterization of antifungal volatile compounds evolved from solarized soil amended with cabbage residues. Phytopathology 83:899-905.

6. Gutierrez, A. P., and DeVay, J. E. 1986. Stud- ies on plant-pathogen-weather interactions: cotton and Verticillium wilt. Pages 205-231 in: Plant Disease Epidemiology: Population Dynamics and Management. Vol. 1. K. J. Leonard and W. E. Fry, eds. Macmillan Publishing Co., New York.

7. Harborne, J. B., and Baxter, H. 1993. Phytochemical Dictionary: A Handbook of Bioactive Compounds from Plants. Taylor and Francis, Inc. Washington, D. C.

8. Johnson, A. W., Golden, A. M., Auld, D. L., and Sumner, D. R. 1992. Effects of rapeseed and vetch as green manure crops and fallow on nematodes and soil-borne pathogens. J. Nematol. 24:117-126.

9. Keinath, A. P. 1996. Soil amendment with cabbage residue and crop rotation to reduce gummy stem blight and increase growth and yield of watermelon. Plant Dis. 80:564-570.

10. Koike, S. T., Subbarao, K. V., Gordon, T. R., Davis, R. M., and Hubbard, J. C. 1994. Verticillium wilt of cauliflower in California. Plant Dis. 78:1116-1121.

11. Mayton, H. S., Olivier, C., Vaughn, S. F., and Loria, R. 1996. Correlation of fungicidal activity of Brassica species with allyl isothiocyanate production in macerated leaf tissue. Phytopathology 86:267-271.

12. Mojtahedi, H., Santo, G. S., Hang, A. N., and Wilson, J. H. 1991. Suppression of root-knot nematode populations with selected rapeseed cultivars as green manure. J. Nematol. 23:170-174.

13. Muehlchen, A. M., Rand, R. E., and Parke, J. L. 1990. Evaluation of crucifer green manures for controlling Aphanomyces root rot of peas. Plant Dis. 74:651-654.

14. Ramirez-Villapudua, J., and Munnecke, D. E. 1987. Control of cabbage yellows (Fusarium oxysporum f. sp. conglutinans) by solar heating of soils amended with dry cabbage residues. Plant Dis. 71:217-221.

15. Ramirez-Villapudua, J., and Munnecke, D. E. 1988. Effect of solar heating and soil amendments of cruciferous residues on Fusarium oxysporum f. sp. conglutinans and other organisms. Phytopathology 78:289-295.

16. Schnathorst, W. C. 1981. Life cycle and epidemiology of Verticillium. Pages 81-111 in: Fungal Wilt Diseases of Plants. M. E. Mace, A. A. Bell, and C. H. Beckman, eds. Academic Press, New York.

17. Sorensen, L. H., Schneider, A. T., and Davis, J. R. 1991. Influence of sodium polygalacturonate sources and improved recovery of Verticillium species from soil. (Abstr.) Phytopathology 81:1347.

18. Subbarao, K. V., Chassot, A., Gordon, T. R., Hubbard, J. C., Bonello, P., Mullin, R. Okamoto, D., Davis, R. M., and Koike, S. T. 1995. Host range of Verticillium dahliae from cauliflower and genetic relationships and cross pathogenicities of isolates from different crops. Phytopathology 85:1105-1112.

19. Subbarao, K. V., and Hubbard, J. C. 1996 Interactive effects of broccoli residue and temperature on Verticillium dahliae microsclerotia in soil and on wilt in cauliflower. Phytopathology 86:1303-1310.

20. Subbarao, K. V., Hubbard, J. C., and Koike, S T. 1994. Effects of broccoli residue on Verticillium dahliae microsclerotia and wilt incidence in cauliflower. (Abstr.) Phytopathology 84:1092.

21. Wilhelm, S., and Paulus, A. O. 1980. How soil fumigation benefits California strawberry industry. Plant Dis. 64:264-270.

22. Xiao, C. L., Subbarao, K. V., Schulbach, K F., and Koike, S. T. 1998. The effects of broccoli residue and irrigation on Verticillium dahliae microsclerotia in soil and wilt in cauliflower. Phytopathology 88:1046-1055. 